\title{
Re-membering with river Daugava: Poetic engagements with water memory
}

\section{SOUND-, LAND- AND STORY-SCAPES OF DAUGAVA}

I am five years old, and I am sitting on a thick branch of a willow tree by the river Daugava. It's a cloudy, overcast day in the summer of 1991. I am singing a song taught to me by my grandmother:

Dzīvīte, dzīīite, šūpojos tevī, Vējā kā žubìte liepzariṇā. Daudz tu man solīji, maz tomēr devi, Vai nav vienalga ar'! Rai-daidai-dā!
Life, sweet life, I am swaying in you

As a bird [sways] in the wind on a branch of a linden tree.

You promised me so much and gave me so little Does it matter after all? ${ }^{1,2}$

I have been sent to stay with my grandfather for a few weeks in a time of unrest in what is still officially Soviet Latvia. He lives in Kegums, a small town on the river Daugava. At my grandfather's I am allowed to do things I never would be at my grandmother's. I walk alone to the river. I approach carefully, trying not to scare the small fish that swim by the shore, but they always sense me coming. Eventually I discover that if I lie flat on my stomach on the concrete blocks used to enforce the shore, watching the river, they swim back into the shallow water just in front of me. I lie there for hours, watching their speedy movements among the weeds, their shadows on the pebbles at the bottom of the river, bubbles and whirls on the water's surface.

Sometimes my grandfather takes me along to the Kegums hydroelectric power plant on the river where he works as an engineer. I roam around in the big building. There are dark rooms and pathways. There is a deafening sound of water falling from an unbelievable height. I watch the falling water through a railing, holding onto it. The enormous building is shaking with the power of the water. I would get lost in the water's movements, but I am too scared by its roaring.

My grandfather dries apples from his garden with the excess heat from the power plant. He lays them out on a newspaper, cut in thin slices. 


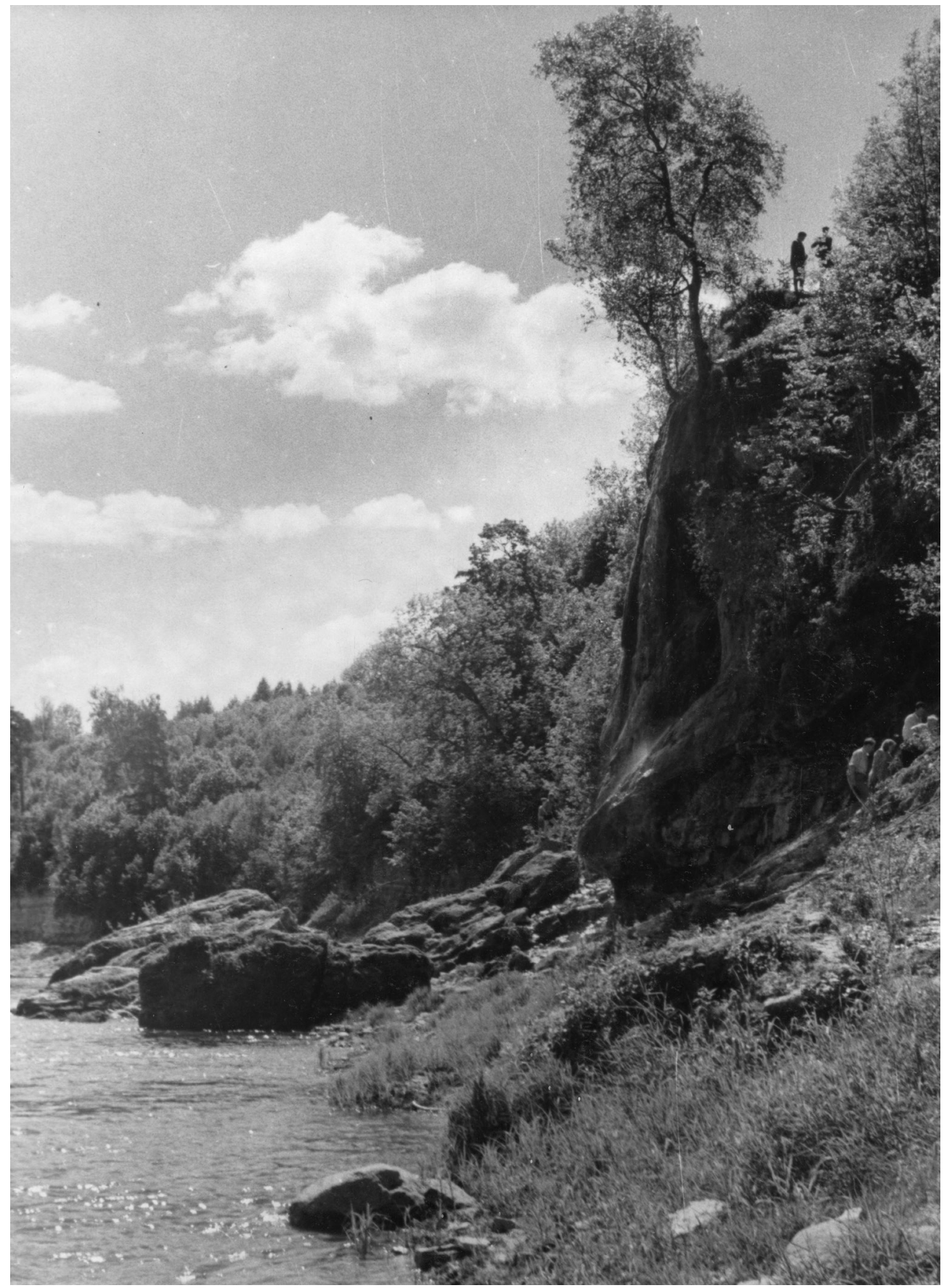

Figure 1. Staburags - the crying cliff on Daugava, before flooding. ${ }^{4}$ 
I hear stories about the river: how, before construction of the hydroelectric station and the dam, people walked over the ice in wintertime. Some winters, the ice was so thick that even trucks could drive over to the other bank. My dad and his sisters went skiing on the river. I hear about a village flooded after the construction of another nearby power plant. How, if one listened, one could hear the bells chiming in the flooded village church from underwater. How the dreaming souls of the previous inhabitants of the drowned buildings would come to the shore at night, looking into the depths with longing, trying to make out their houses in the moonlight.

My dad tells me about how the Kegums bridge, connected to the dam, once collapsed as its carrying ability was tested by Soviet tanks. I imagine the massive tanks falling into the water, consumed by the river, disappearing.

\section{LIKTENUPE: DAUGAVA, THE RIVER OF DESTINY}

Daugava is the biggest river in Latvia. Also known as Western Dvina, it originates in Russia and flows through Belarus and Latvia, joining the Baltic Sea in Riga, the Latvian capital. In Latvian mythology, Daugava often figures as Daugava māmuḷ (mother), as well as Liktenupe- the river of fate and destiny. According to Latvian folk songs, it carries the pain, blood and tears of Latvian people to the sea; it is full of precious souls.

In the twentieth century, predominant modes of relating to Daugava have been those of natural resource extraction, contrasted by perceiving Daugava as a bearer of Latvian identity to be protected against Soviet violence. In the 1960s, the Soviet regime constructed a power plant named after Lenin on the river Daugava in Pliavinas, around $30 \mathrm{~km}$ upstream from Kegums: the biggest hydroelectric power plant in the Baltic countries and the second biggest in Europe. This was the construction that drowned the village whose inhabitants, I heard, still came to look for their houses while asleep.

"On June 16th, the builders set out to attack Daugava. 80 tipper trucks assaulted the surging current from both banks. 11.10- the shores have met! The victory of the builders is an anniversary gift to Soviet Latvia."3

This triumphant description comes from the cinema magazine 'Soviet Latvia.' However, the construction of the dam and building of the hydroelectric plant had grave ecological and cultural costs. The most often commemorated loss brought by the construction of the Plavinas power plant is the flooding of Staburags. Staburags was a lime-rich cliff on Daugava, a national symbol whose cultural significance is difficult to convey to non-Latvian readers. After the flooding Staburags became an even more powerful image, its loss symbolizing the loss of Latvia's independence and Soviet oppression.

In the mid-1980s, Daugava again became a national symbol in protests against the construction of yet another power plant in Eastern Latvia, which would have entailed the flooding of culturally and ecologically important landscapes and forced relocation of numerous people. Despite attempts to banish the word "Daugava" from public discourse, the movement against the new power plant managed to collect between thirty to forty thousand signatures. In late 1987, the Soviet Counsel of Ministers announced a halt to the project. These events became a key moment in the national awakening of the late 1980 s. $^{5}$ 
However, the exploitation and resource extraction for electricity from Daugava did not begin in the Soviet period. The Kegums hydroelectric plant that my grandfather worked on was built in 1930s during a dictatorship in the first period of Latvian independence (1918-1940). In Latvia, the dictatorship is often glorified as a period of economic prosperity, progress and freedom, as opposed to the subsequent Soviet occupation and the preceding centuries of foreign rule.

These dynamics of remembering and silencing injuries and exploitation of Daugava by different regimes and national independence struggles in the twentieth century form a background to the story I want to tell. I want to explore how the river enables re-membering untold histories and living with loss. I take a point of departure in my own family history, reflecting political and societal processes in Latvia: my grandfather's life on the shores of the river Daugava after he returned from exile in Siberia and my own experiences from being with the river as a child. I bring this family history, gathered from my memories and conversations with my father, in dialogue with Latvian folk songs, Edouard Glissant's ${ }^{7}$ writings on embodied memories of trauma, Indigenous perspectives on co-becoming with territory ${ }^{8}$ and perspectives from feminist new materialisms. ${ }^{9}$

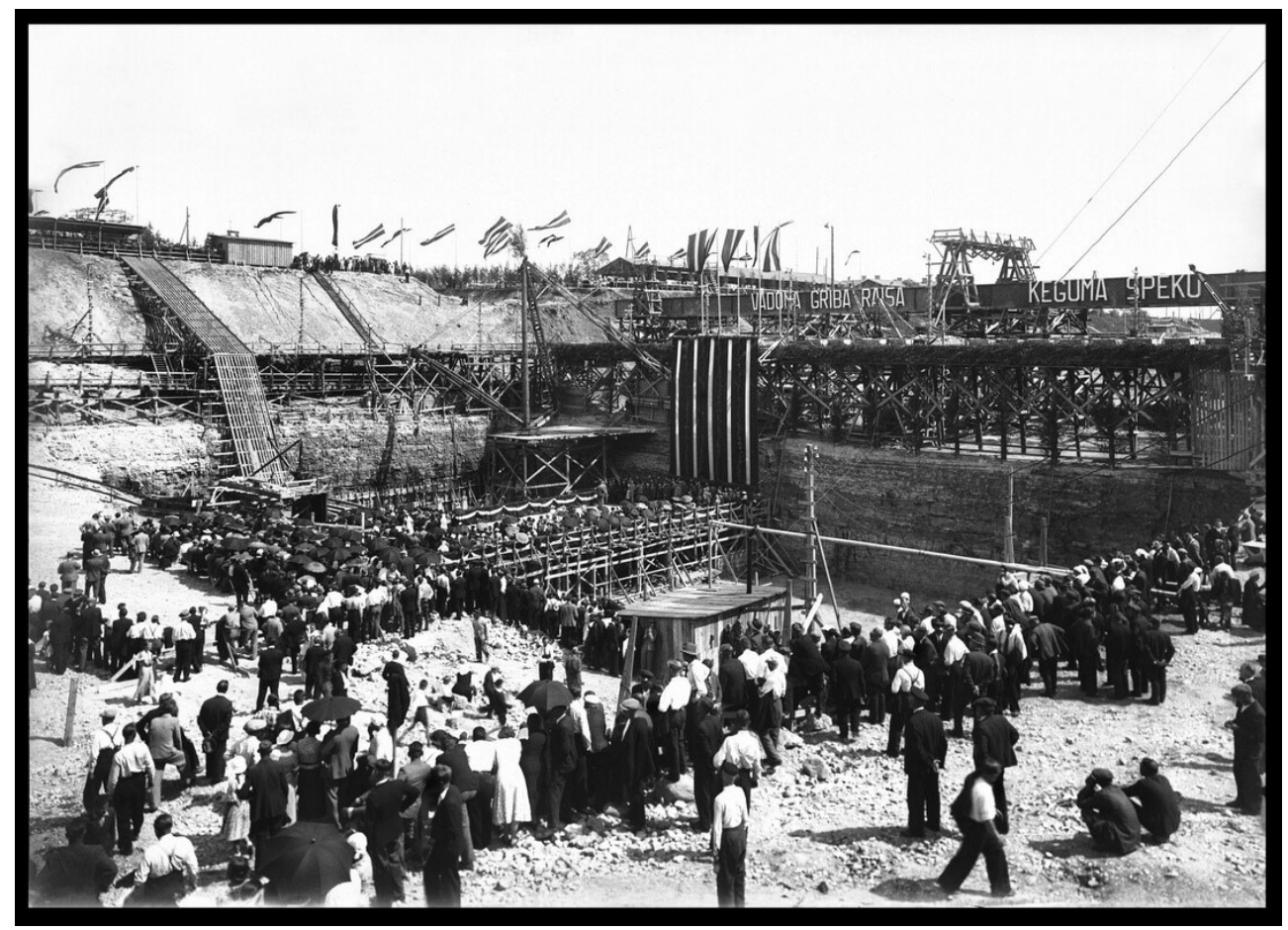

Figure 2. Eduards Kraucs, "The construction of Kegums Hydro Powerplant, the founding stone laying ceremony, May 22, 1937." Image courtesy of the Latvenergo Energetics Museum collection. The banner on the dam reads "The will of the Leader calls for strength from K, Kegums". 6 


\section{ENGINEER AND GARDENER}

My grandfather was deported to Siberia in 1949, together with his recently widowed mother and two younger brothers. He was 12 years old, his brothers aged nine and eight. The deportations were carried out to cleanse the Soviet social body from undesired elements. The official target were kulaki, ostensibly prosperous enemies of collectivization. My grandfather's family had owned a horse and two pigs, 32 hectares of land and the house they lived in. After her husband's death, my grandfather's mother had signed a waiver that she refused any rights to their land, and yet she found herself on the train with her three sons.

My grandfather died in 1998, when I was 12. I never heard him mention the time in Siberia. According to my father, he spoke about some things from these years: the other families in the barracks, the local language and customs, the winter snowstorms, the fertile soil, the harvests in the collective farm. He never spoke about enduring hardship. Yet my grandfather's mother was never again able to work after returning to Latvia. Her health had suffered from the physical labor of cutting trees.

My grandfather and his brothers attended the local school. In 1956, three years after Stalin's death, he started studying at the university in Tomsk. It was possible to transfer to another Soviet university with the purpose of changing the focus of one's studies. Already in 1957, my grandfather applied for transfer to study electro energetics in Riga, Latvia. Somehow his application was approved. There was a thaw after Stalin's death, and the official granting the approval might have overlooked the deportation record.

After graduating in 1961, my grandfather was assigned to work in the hydroelectric power plant in Kegums. He lived in Kegums for the rest of his life. His brothers and mother managed to return to Latvia in late 1950s and settled close to the village where their home had been, although other families now lived in the house that had been theirs.

When I remember my grandfather, I remember the garden he tended close to the river. For me as a child, the river seemed further away - there was another garden or two between my grandfather's garden and the grassy meadow and a volley ball field by the riverside. Yet Daugava's gleam was visible through the trees and bushes from the garden. I remember the pear tree by the old shed, the raspberry bushes, the apple and cherry trees. I remember the smell of the hyacinths my grandfather cultivated in wooden boxes in the veranda in his apartment in the early spring: purple, pink, white. I remember the protruding tendons and everpresent small scratches on his hands. He was a bent, skinny man, but for me his hands were the embodiment of strength and endurance.

Last summer, after I interviewed my father about my grandfather, he found a book in the attic: a graduation present from my grandfather's teacher in the local school. The book bears the following inscription: 


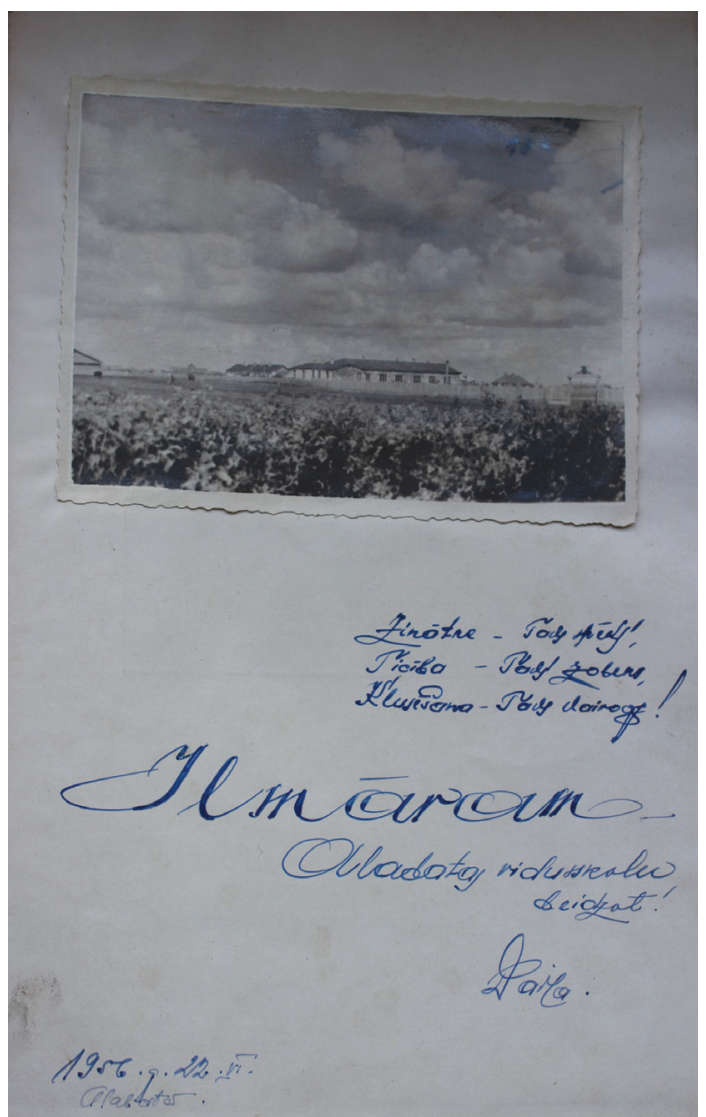

"Knowledge - your strength! Faith - your sword,

Remaining silent - your shield!"
Figure 3. Inscription in a book presented to my grandfather (IImārs) upon graduation from Aladata highschool, dated June 22, 1956.

(translation to side).

\section{RE-MEMBERING (WITH) DAUGAVA}

Visas upes cauri jāju, Daugavinu nevarēju, Daugavinu nevarēju, Tā bij pilna dvēselīšu.

Daugavina, melnacīte, Melna tek vakarā.

Kā tā melna netecēs, Pilna dārgu dvēselī̌su.

Sīku loku upe tek, Zaru, zaru Daugavina. Upe loku pieñēmuse, Daugaviña dvēselīšu.
I rode through all the rivers I couldn't [ride through] dear Daugava I couldn't [ride through] dear Daugava [For] it was full of precious souls.

Daugava, sweet black-eye, Runs black in the evening. How will it not run black, [As it is] full of precious souls.

A river runs with small bends Dear Daugava ${ }^{10}$ curves and curves A river has bends

Dear Daugava is full of precious souls. ${ }^{11},{ }^{12}$ 
I remember my grandfather as taciturn, hard-working, silent but kind. I was never afraid of him.

I wonder about the shields: silences and absences in my grandfather's and my father's stories. I wonder about how the river can help me re-member my grandfather and where I come from. These songs cast Daugava as different from all other rivers as it is full of precious souls. This notion relates to that of Daugava as Liktenupe, the river of fate and destiny, carrying suffering to the sea. To understand how Daugava embodies loss and pain, I turn to Edourard Glissant's insights on the body, intergenerational trauma and histories of violence.

Analyzing Edouard Glissant's writings from and about violent histories in the Caribbean, Michael Dash evokes the phrase "poetics of re-membering"13 to show how Glissant's focus is on the (violated) body, recognizing it as a shaping force and vehicle of memory. The mind may attempt to forget, shielding itself behind silence. In contrast, bodies bear experiences of past violations - even if these remain absent from verbal accounts.

Instead of locating consciousness and agency in the (human) body, Glissant's work places it in relationships between interconnected bodies “(...) scattered throughout Caribbean history. It is the sea that holds the secret of the bodies of Carib suicides as well as slaves thrown overboard which are part of the remembered we." 14

\section{Glissant writes:}

The French Caribbean is the site of a history characterised by ruptures (...) that began with a brutal dislocation, the slave trade. Our historical consciousness could not be deposited gradually and continuously like sediment [...] but came together in the context of shock, contradiction, painful negation, and explosive forces. The dislocation of the continuum, and the inability of the collective consciousness to absorb it all, characterise what I call nonhistory. ${ }^{15}$

I do not mean to compare the violent histories of today's Latvia and the French Caribbean: the disposability of the enslaved bodies thrown overboard from ships and the serf souls carried by Daugava or the bodies deported to Siberia by the Soviet regime centuries later. However, Glissant's insights on how 'nonhistory' or unvoiced history results from a traumatic dislocation of body and consciousness, ${ }^{16}$ and how this history can be held by the sea, informs my understanding of the embodied re-membering of Daugava.

In order to understand the relationality or intra-action ${ }^{17}$ between my grandfather and Daugava, I turn to Bawaka Country et al. ${ }^{18}$ insights on co-becoming of 'nature' and human bodies. The fact that Bawaka Country (a Homeland located in Australia) is the first author of their texts reflects the authors' understanding of co-becoming of bodies and knowledges: “(...) more-than-humans and humans co-become as place/space, in deep relation to all the diverse co-becomings that also constitute it. Space/place is its doings, its beings, its knowings, its co-becomings." 19

A final perspective on the intermeshed, co-dependent embodiment of Daugava and the beings on its shores comes from feminist new materialisms. In an interview from 2017, Elizabeth Povinelli ${ }^{20}$ asks: "What if everything was everything else's external organs?" 
This question echoes Stacy Alaimo's notion of transcorporeality, which refers to the contact zone between human and more-than-human natures, emphasizing that bodies are never autonomous but emerge through interactions with the materialities that surround them. ${ }^{21}$ Writing about the remembering done by Daugava, I aim to: (...) activate and amplify the more-than-human modes of living that are also always part of existence and part of our 'own' corporeality, and which emerge from our particular politics of location. ${ }^{22}$

The insights on co-becoming by Bawaka Country et a ${ }^{23}$ make me wish that I could let Daugava speak through me. Yet, writing from Copenhagen where I have lived as a migrant for the past 16 years, I feel too far from her (them/it), even as she is in my body. Perhaps I am writing with her, and she is writing with me. In the last part of this text, I want to make myself attuned to hear and sense her flow in and through me.

\section{Re-membering:}

(...) the material reconfiguring of spacetime mattering (...) to account for the devastation wrought as well as to produce openings, new possible histories by which time- beings might find ways to endure. ${ }^{24}$

Karen Barad

Glissant writes: "To live the world-totality from the place that is one's own means to establish a relation, not consecrate exclusion." ${ }^{25}$

"I" am looking for my relations. Writing from Copenhagen, "I" am listening for, re-membering, a place of my own. This place is more than a physical place - it is a way of sensing and being. I recall watching fish in the shallow water by Daugava's shore.

"I" am tracing the distribution of memory in my external organs. This exercise involves re-shuffling fragments of sensory impressions, images and feelings - and it brings about a rupturing, an overflow.

\section{What surfaces:}

the deafening roar of the falling water in the power plant I got lost in as a child visiting my grandfather at work. No one was wearing hearing protection. Working on the power plant, my grandfather was complicit in the wounds inflicted upon the river. He was shaken by its roar, immersed in its cries every day.

my grandfather's figure, slightly bent, like a birch tree growing in a harsh climate, hardened by cold winters. Stiffened.

his face marked by the ambiguity of the reflections cast by the water. The black-and-white photo I best recall him from, one that I have not been able to find, shows his head above the water while swimming in Daugava. He is smiling, illuminated by reflections of light from the water.

My grandfather's body:

a stiffness of a tree

the bends of Daugava. 
One of the folk songs underlines how Daugava's bending is different from that of other rivers, due to the precious souls it carries. There is a location on the river, upstream from where my grandfather lived, called Daugavas loki (Daugava's bends), which is among the natural sites that would have been destroyed in the building of the dam that was planned in the mid-and late 1980 s. At the same time, the river has been bent by human hands, its course and depth changed by the power plants.

Being bent by other forces than what feels like one's own volition.

Perhaps, in contrast to Glissant's ${ }^{26}$ wording, the continuum (of memory, of existence) was never there to have been dislocated; the sediment of history was always being flushed away; the precious souls of Daugava never to be recovered. The river as living nonhistory, beyond the impulse to (re) claim or articulate it.

Re-membering: bending, enduring. Patterns of light broken by the water's surface.

One endures through bending. One bends to survive, and that movement changes one's way of being with the world. Transcorporeality emerging through movement: flow, bending, a deafening roar.

What does it mean to live a destiny carried away from one, as one is standing on the shore?

\section{POLITICS AND POETICS OF IMPERMANENCE}

By carrying suffering, blood and tears, the river cares, it heals. Being carried is not a disappearance or absolution; it is a holding, a keeping. Of the tiny fish I watched from the shore, Soviet tanks, the drowned village. It passes, we pass. Nothing is kept in place, only attended to. ${ }^{27}$ That which passes (by): a letting go, a loosening.

A fate contained in letting pass by.

Daugava bends and re-members, cares and carries. It bears trace and witness. A flowing, sensing archive. It holds. We are each other's external organs. Liktenupe - one's fate being carried to the sea, escaping one. Unknown and unknowable, as it passes by. Memory as exactly that which is not retained, held onto, constricted.

A re-membering that loosens and extends.

Daugava is falling towards the sea. Falling in and out of place, falling into flow. Flow: not a rushing onwards, but a leaning into. Facing backwards while being on a train, carried towards an unknown destiny/destination, one's back the surface of perception of the unknowable to come.

I feel from Daugava that destiny cannot be claimed. A fate that flows by. A fate that is not about willfully adding new things, acquisition, accumulation. Something erodes, and something flushes up on the shore.

Daugava embodies politics and poetics of impermanence. Matter as impermanence, broken down and eroding. The shore of the river during a flood. The flooding of Staburags. We, things, places do not, cannot last. An unfolding that is not generation, but erosion.

A fate beyond fixity, full of souls. 
Re-membering: letting go. Re-membering as a loosening, losing, like a knot that is actually a weaving, that contains multiple events, forces, relations. Ongoingness.

The river teaches me to remain, endure, as I let go. To attend to the flow without penetrating the surface.

To suffice, to carry (on), to be carried, without knowing the impulse to hold on to because nothing offers itself as an anchor. Falling into flow, time lifts and expands. It is a duration that is made up of passing by.

Being embraced, the river is my bloodflow.

Linda Lapina. ( () ORCID No 0000-0002-3562-6949) Assistant Professor of Cultural Encounters, Roskilde University - I am a researcher, a dancer and a migrant. I am interested in embodiment, affectivity, space and time, approached through the lens of feminist theory. My research areas include: racialisation, whiteness, intersectionality and everyday bordering; contested urban spaces; feminist new materialisms and embodied, more-than-human memory; intersectionality applied to teaching and knowledge production; affective and artsbased methodologies.

1. Z Sneibe, "Latvian Folk Songs in the 18th-19th Centuries: Tradition and Change," in Historical Studies on Folk and Traditional Music: ICTM Study Group on Historical Sources of Folk Music, Conference Report, Copenhagen, ed.s D Stockmann and J H Koudal (Copenhagen: Museum Tusculanum Press, 24-28 April 1995): 59-68.

2. This song is a part of the zinge (from the German verb "singen", to sing) musical and literary tradition in Latvia. This song tradition originated in the late eighteenth century with the work of Gottfried Friedrich Stender, a Baltic German pastor who published a book called Jaunās zinǵes (New zinǵes) in 1774. Stender wanted to provide Latvian serfs with a moral education, instilling obedience, servitude and what he saw as emotional refinement and maturity (Sneide 1995). In contrast to Latvian folk songs and poetry, zinǵe texts are more dramatic, often detailing romantic fortunes and misfortunes, the importance of hard work, morality, death and tragedy. The zinge I sang by the river is from the beginning of 20th century, based on a poem by the Latvian poet and teacher Fricis Bārda (1880-1918). 
3. Quoted from Guntars Laganovskis' "Daugavas liktenis - izglābt sevi un tautu caur neiespējamo," LV Portals, September 29, 2017, accessed May 18, 2020, https://lvportals.Iv/norises/290092 daugavas-liktenis-izglabt-sevi-un-tautu-caurneiespejamo-2017.

4. Photo credit: Daugava Museum, https://diena. Iv/raksts/kd/kd-afisa/izstade-_daugavaibut_-14181082 accessed May 27, 2020.

5. Laganovskis, "Daugavas liktenis."

6. Photo credit: Latvenergo, http:// energetikasmantojums.Iv/keguma-hes-no-idejaslidz-musdienam/, accessed May 27, 2020.

7. See Michael Dash, "Writing the Body: Édouard Glissant's Poetics of Re-membering," World Literature Today 63, no. 4 (1989): 609-612; Édouard Glissant, Poetics of Relation (Ann Arbor: University of Michigan Press, 1997); and Carole Sweeney, "The Unmaking of the World: Haiti, History, and Writing Édouard Glissant and Edwige Danticat," Atlantic Studies 4, no. 1 (2007): 51-66, https://doi.org/10.1080/14788810601179550.

8. Bawaka Country, Sarah Wright, Sandie SuchetPearson, Kate Lloyd, Laklak Burarrwanga, Ritjilili Ganambarr, ... Jill Sweeney, “Co-becoming Bawaka: Towards a relational understanding of place/space," Progress in Human Geography 40, no. 4, (2016): 455-475, https://doi. org/10.1177/0309132515589437.

9. See Stacy Alaimo, Bodily Natures: Science, Environment, and the Material Self (Bloomington: Indiana University Press, 2010); Karen Barad, Meeting the Universe Halfway: Quantum Physics and the Entanglement of Matter and Meaning (Durham and London: Duke University Press, 2007); Astrida Neimanis, Bodies of Water: Posthuman Feminist Methodology (Bloomsbury Academic, 2016); and Elizabeth A. Povinelli, Mathew Coleman, and Kathryn Yusoff, "An Interview with Elizabeth Povinelli: Geontopower, Biopolitics and the Anthropocene," Theory, Culture and Society 34, no. 2-3 (2017): 69-185, https:// doi.org/10.1177/0263276417689900.

10. "Daugavina" and "dvēselītes" are diminutive forms of "Daugava" and "dvēseles" (souls). The use of nouns in diminutive in Latvian indicates that the bespoken entity is precious, dear, cherished.

11. See leva Zake, "Inventing Culture and Nation: Intellectuals and Early Latvian Nationalism," National Identities 9, no. 4 (2007): 307-329, https://doi.org/10.1080/14608940701737359; and Vaira Vikis-Freiberga, "Sink or Swim: On Associative Structuring in Longer Latvian Folksongs," Oral Tradition 12 no. 2 (1997): 279307.
12. These are three unconnected folk songs. For hundreds of years, Latvian folk songs or dainas were an oral cultural tradition. They began to be systematically collected in the beginning of 19th century by "Young Latvians", young, ambitious university-educated men, self-identifying as Latvian and seeking to establish their ethnic identity: a national culture, language and historical origins (Zake 2007, 314). The main source of dainas is the collection of over 200,000 written versions classified and published by one of the most influential "Young Latvians", Krišjānis Barons (1894-1915), where a "song" is generally presented as a "brief, epigrammatic quatrain unit" (Vikisis-Freiberga 1997, 279). In this text, I do not approach folk songs as "pure" sources of a recovered (Latvian) ontology; however, I believe they contain knowledge about Daugava that might be hard to find elsewhere.

13. Dash, "Writing the Body."

14. Ibid, 612. I propose that Dash means "the remembered we."

15. Glissant, Poetics of Relation, 61-62.

16. Sweeney, "The Unmaking of the World," 52.

17. Barad, Meeting the Universe Halfway.

18. Bawaka Country et al., "Co-becoming Bawaka."

19. Ibid, 456.

20. Povinelli et al., "An Interview with Elizabeth Povinelli," 180.

21. Alaimo, Bodily Natures.

22. Neimanis, Bodies of Water, 63. Emphasis in the original.

23. Bawaka Country et al., "Co-becoming Bawaka."

24. Karen Barad, "Troubling time/s and ecologies of nothingness: re-turning, re-membering, and facing the incalculable," New Formations 92, (2017): 56-86, https://doi.org/10.3898/NEWF.

25. Édouard Glissant and Pierre Joris, "From Introduction to a Poetics of the Diverse," boundary 2 26, no. 1 (1999): 120.

26. Glissant, Poetics of Relation.

27. Povinelli et al., "An Interview with Elizabeth Povinelli." 